\title{
LEARNING FROM THE WISDOM OF THE PROPHETS: SPIRITUAL INTELLIGENCE OF HŪD AND MUHAMMAD IN IBN ARABI'S VIEW
}

\author{
Andi Herawati \\ Sekolah Tinggi Filsafat Islam Sadra (STFI), Jakarta. \\ E-mail: andi.hera1@yahoo.com
}

\begin{abstract}
The wisdom of the prophets in Ibn 'Arabi's Fususs alHikam is deeply concerned with discovering how the prophets who are taken up in each chapter exemplify different facets of the deeper spiritual process of the divine-human relation. This article examines two particular fass and wisdom of Hūd and Muhammad. The wisdom of Hud represents knowledge through the feet" (ilm al-rij), the knowing that can only come through actually traveling through all the tests and lessons of the earthly human existence or suluk, while the wisdom of Muhammad defines the role of love and its multiple layers. Both are seen to be a spiritual intelligence of the prophets. Spiritual Intelligence empowers people to deal with and resolve life-world issues while demonstrating virtuous behavior such as humility, compassion, gratitude, and wisdom. For Ibn 'Arabī, spiritual intelligence is about discovering intrinsic distinctions between truth and illusion, and spiritual discernment, is all about. Finally, through his particular work, Ibn 'Arabì highlights and assumes a recurrent progression from habitual conditioning that human usually encounter to a greater depth and breadth of consciousness.
\end{abstract}

Keywords: spiritual, intelligence, tahqiq, realization, wisdom, path, love, discern.

DOI: http:// dx.doi.org/10.20414/ ujis.v20i2.821 


\section{Introduction}

GOD has communicated to human beings in many different ways. According to the Qur'an (Q. 42:51), He speaks to us "through revelation or from behind a veil" So the ways God communicates with us are according to our capacity to understand it. However, it is not always easy to understand the ways God speaks to us, and the spiritual "knowers" ("urafa') often remind us that there are certain basic reasons that obscure us from seeing the realities intended by what God speaks. One of those obstacles is that we are today largely unfamiliar with the traditional spiritual perspective that views all things as the manifestations or theophanies of God's infinite Names and Attributes. Furthermore, the analytical and conceptual human mind naturally works by seeing things as separate and distinct, often through contrasts and oppositions (far-near, west-east, bad-good) and through judgments that are based on such unconscious conceptual oppositions. In consequence, people tend to consider those who are distinguished or different from them as unbelievers, wrong, heretics, ignorant - a tendency that at worst can lead to extreme forms of conduct.

In such a perspective, different realities of the observable world $^{1}$ that initially seem unrelated to us may have an inward affinity (munāsaba) because in fact they manifest the same divine Name. ${ }^{2}$ For Ibn 'Arabī, therefore, because the Prophetic revelation is necessarily addressed to all people, it must convey meaningful messages to the spiritual elite as well as to the generality of the people; and the plural here means that those "messages" are likely to be different, and understood differently, by people of different aptitudes and experience, in different situations and circumstances. ${ }^{3}$

1I.e., the divine "Signs on the horizons and within the souls" (41:52).

"William C. Chittick, "The Chapter Headings of the Fuṣuṣ," the Journal of the Mubyiddin Ibn 'Arabi Society 2 (1984): 3.

${ }^{3}$ Andi Herawat, "Concerning Ibn 'Arabi's Account of Knowledge of God (Márifa) al-Haqq," Kanz Philosophia : A Journal for Islamic Philosophy and Mysticism 3, no. 2 (2013): 219-42, http://dx.doi.org/http://dx.doi.org/ $10.20871 /$ kpjipm.v3i2.49. 
In our day, we are still familiar with the stories of the prophets $^{4}$ as playing such a revelatory spiritual and prophetic role, but we have less understanding what meanings lie behind the existence of those prophets. On the other hand, the Sufis have often quoted and mentioned the spiritual teachings of the prophets using the interplay of the symbols or allusions in order to let us to understand how God teaches us through parables, symbols, and stories. Ibn "Arabi is one of most prominent Muslim thinkers, Sufis and "knowers" who very often uses that kind of interpretive approach. ${ }^{5}$ For example, in his famous Fusüs al-Hikam he uses the Qur'an's allusions to Moses and Khezr, Noah and his people, Hūd and his people, or Adam, the angels and Iblis. To take just one illustrative example (among countless others) from the Qur'an, Ibn 'Arabī makes it clear just what and how Khezr knows what the younger Moses fails to know, ${ }^{6}$ and why it is that spiritually alert patience (sabr) is the essential practical spiritual element that separates the two of them.

However, we may also stress that it is very difficult to even begin to contemplate the many facets of the complex relationship between the prophets and their people, without simultaneously discovering and examining familiar living examples of those relations. Besides that, in the history of Islamic civilization there has been deep devotion that pulsates through the heart of every Muslim toward the beloved personality of the holy prophets. ${ }^{7}$ They are indeed living

4For example, see Imām 'Imād al-Dīn Abū al-Fidā' Ismā'îl ibn 'Umar Ibn Kathir, Stories of the Prophets (Riyad: Maktabah Dār al-Salām, 2003). Martin Lings, Mubammad: His Life Based on the Earliest Sources (Lahore: Suhail Academy, 1983). Muhammad ibn 'Abd Allāh al-Kisā'i, Tales of the Prophets (Qisạs al-Abiyā') trans. Wheeler Thackston (Chicago: Great Books of Islamic World, 1997).

5Lihat James Morris, "Arabī and his Interpreters," the Journal of the American Oriental Society 106 (1986): 539-51.

"Qur'an 18:68. Khezr's explanation to Moses there fully reads: "And bow should you bear patiently that you have never encompassed in knowledge?" See, Caner K. Dagli, Ibn 'Arabi: The Ringstones of Wisdom, trans. Caner K. Dagli (Chicago: Great Books of the Islamic World, 2004), 246.

${ }^{7}$ For example, Muhammad who had provided what the Qur'an calls "a beautiful example" of the way to live in accordance with God's will, which Muslims from then until today have endeavored to emulate. 
examples, as Qur'an remains 'It is $\mathrm{He}$ who has sent among the unlettered a Messenger from themselves reciting to them $H$ is verses and purifying them and teaching them the Book and wisdom" (Q. 62:2).

For all these reasons, it is extremely important to "revitalize" our understanding, beyond the apparent teachings of the prophets, by also integrating the inner spiritual aspect of their lives and teachings, since they have been divinely appointed as exemplars for mankind for all ages. Their messages are perennial. It is for these reasons that great saints (awliya' Allab) and accomplished Sufi teachers, such as Ibn 'Arabi, constantly remind us all that the divine revelation comes down to us through the language of those divinely designated "Interpreters" (tarjuman, as he describes his own spiritual role in his famous Prologue to the Fususs al-Hikam) who are the prophets and all of the "Friends of God."

In this article we'll try to shed some light on Ibn 'Arabi's efforts to help us understand how God teaches us through parables, symbols, and stories, focusing on his carefully skillful use of the interplay of symbols and allusions to help his students become more receptive to that symbolical and deeper meaning of revelations and the divine "Signs" they are meant to illuminate. The ultimate aim of this research is therefore to seek guidance and illumination in the texts of Muhyiddin Ibn 'Arabī in order to gain understanding and a deeper appreciation of what can be learnt spiritually if we contemplate the deeper divine wisdom provided, in this case, by prophet Hūd (and Muhammad).

\section{Ibn 'Arabī and His Fuṣụs al-Ḥikam}

Abū 'Abd Allāh Mụ̣ammad ibn 'Al̄̄ ibn Muḥammad ibn 'Arabī al-Hātimī al-Ṭā' $\overline{1}$, more commonly known as Ibn 'Arabì (1165-1240), was an Andalusian scholar of Islam, Sufi mystic, poet, hadith scholar, and philosopher-theologian. ${ }^{8}$ His life and works came to deeply influence all schools of later

${ }^{8}$ For more detailed access about Ibn 'Arabi life and works, see for example, William C. Chittick, Ibn 'Arabi, Heirs to the Prophets (England: One World, 2005). 
Islamic thought and creative figures in the Islamic humanities, so that he became widely known as al-Shaykh al-Akbar, "the Greatest Sheikh."'Over the past century, he has become almost as widely known and influential, so that his translated works are today cited by scholars and creators globally.

Ibn 'Arabì was particularly well known in the Muslim East, beyond the Arabic-speaking world, for his distinctive metaphysical system - so much so that he was widely considered as a founding father of the later Islamic traditions of "contemplative mysticism" ('irfän). In his own works, he often speaks of the accomplished spiritual "knowers," or 'ärifün," as the highest among the many friends of God; and he often calls the true knower a muhaqqiq, meaning the "person who (experientially and thoughtfully) realizes" the divine Truth or Reality. That key term itself helps to bring out the particularly comprehensive, wider illuminated vision of the 'arif in relating himself to every dimension of reality, an ongoing spiritual realization that is rooted in the spiritual practice and true perception of reality, including all the phenomena or divine "Signs" of life and creation.

He constantly took up this point concerning the underlying reality of the Divine Names or attributes throughout his many works, especially his famous Fusüs al-Hikam, ${ }^{10}$ the late summary work traditionally considered as the pedagogically useful synopsis of his principal ideas. His approach there moves back and forth between allusions to the divine Essence, on the one

'Or 'urafa': both plurals of 'arif, from the same Arabic root as ma'rifa. See, William C. Chittick, The Sufi Path of Knowledge: Ibn al-'Arabi's Metaphysics of Imagination (Albany, NY: State University of New York Press, 1989), 147-8.

${ }_{10}$ Considered by many scholars as a difficult text that cannot be understood without detailed explanation; hence the production of hundreds of commentaries in later centuries. No other book of Ibn 'Arabī has been as widely read or commented upon as Fușuss al-Hikam, though according to recent students of his work (including Chittick and others), the philosophical focus of the commentaries on the Fușuss has often appealed to intellectuals (both today and in the past) relatively less interested in the wider dimensions of spiritual practice that are more prominent and explicitly stressed in most of Ibn 'Arabîs works, including his lengthy Futühät (See Morris, "Arabī and his Interpreters." 
hand, and to the ontological level of "Divinity" (ulühiyya) or the manifestations in all creation of the divine Names, on the other hand, in order to explain how human beings can actually worship - and eventually come to truly "know" - the humanly accessible and essential dimensions of what at first might appear as the absolutely unknowable Essence.

Throughout the Fusūs, Ibn 'Arabī shows how the symbolic, apparently "anthropomorphic" language (tashbih) employed by the successive divine messengers--like their very human form itself--suggests the proper means to lead us toward deeper and more comprehensive knowledge of God, reminding us that the language of revelation must be according to the language of its intended human audiences. Yet since each Prophet and Friend is also an "Interpreter" (for those same human audiences) of the divine "Speech" constituting all creation, so the language of the prophets is likewise a divine Speaking. Thus all prophetic language must express that divine awareness according to a particularly human language which might be understood effectively and convincingly for its ultimate purpose of guiding all human beings - at their many spiritual levels and receptivities--toward their ultimate end as effectively as possible.

Ibn 'Arabī, particularly in the Fusüs, often uses paradoxical or mysterious expressions clearly intended to provoke his students and readers to delve more deeply toward a profound, more adequate understanding of God's Speech and His creation. For in the case of Fususs al-Hikam, since the explicit title and subject of this book itself is divine "wisdoms" (bikam) associated with each prophet mentioned explicitly in the wider Muslim tradition, it is deeply concerned with discovering how the prophets who are taken up in this work each exemplify different facets of the universal spiritual process of the divine-human relation-or of the mutual divine-human calling and response, or attentive and active "listening"- that is so often mentioned in the Qur'an: "Surely there is a Reminder in that for whoever has a heart, or listens attentively, while he/He is witnessing" (Q. $50: 37) \cdot{ }^{11}$

${ }^{11}$ Listening as contemplation by the purified Heart, from James Morris, The Reflective Heart: Discovering Spiritual Intelligence in Ibn 'Arabi's Meccan 


\section{Spiritual Intelligence and Its Dimensions}

The term spiritual intelligence has been a prominent topic among scholars in recent years. ${ }^{12}$ The proponents of the SQ construct have argued that it is distinct from traditional personality traits and general mental ability and that it is a meaningful construct that can be used to explain various psychological and managerial phenomena. Spiritual intelligence is further defined as the ability to construct meaning through intuitively seeing interconnectedness between life-world experience and the inner spheres of the individual psyche. It is also what Emmons (1999) asserts as when persons have the capacity to demonstrate a heightened consciousness of transcendence possessing spiritual intelligence. ${ }^{13}$ Spiritual intelligence empowers the individual to cope with and resolve life-world issues while demonstrating virtuous behavior such as humility, compassion, gratitude, and wisdom. Thus, he describes spiritual intelligence as a cognitive ability to envision unrealized possibilities and transcend ordinary consciousness through applying basic thought processes that have both temporal and existential meanings. ${ }^{14}$

In order to develop an appropriate approach to understanding Ibn 'Arabi's guiding ideas, it is important to appreciate that his particular style of spiritual expression in this work $^{15}$ is devoted to providing or eliciting in his reader certain

Illuminations' (Louisville KY: Fons Vitae, 2005), 46. The same verse figures prominently here in the fass of Shu'ayb, in Ibn 'Arabi's discussion of the true spiritual Knowers ('urafä).

${ }^{12 R}$ R. A. Emmons, "Is Spirituality an Intelligence? Motivation, Cognition and the Psychology of Ultimate Concern," The International Journal for the Psychology of Religion 10, no. 1 (2000). R. A. Emmons, "Spirituality and Intelligence: Problems and Prospects," The International Journal for the Psychology of Religion 10, no. 1 (2000).

13R. A. Emmons, The Psychology of Ultimate Concern: Motivation and Spirituality in Personality (New York: Guilford Press, 1999).

${ }^{14}$ Barbara B. Howard, Precious Guramatunhu-Mudiwa, and Stephen R. White, "Spiritual Intelligence and Transformational Leadership: A New Theoretical Framework," Journal of Curriculum and Instruction (JoCI) 3, no. 2 (2009): 54-7.

${ }^{15} \mathrm{Dagli}$ in his dissertation mentioned that much of the earlier Islamic material relevant to the interplay of conceptual and technical language and 
indispensable keys to his language and intentions, which can be summarized as what has been called a certain "spiritual intelligence," within a more universal phenomenological context of realization. ${ }^{16}$ Self realization is the art of living, and from such perspective, it is an objective of traditional education. ${ }^{17}$ Those features can be explained and elicited through various approaches.

First, an ability to distinguish between what is true/real and illusion. There are certain critically important distinctionseither between what is true and false, or what is real and what is illusory or misunderstood - that actually operate within each level or dimension of knowing. Discovering those intrinsic distinctions is what spiritual discernment, or intelligence, is all about. For example, Ibn 'Arabî's writing highlights and assumes a recurrent progression from habitual conditioning that human usually encounter to a greater depth and breadth of consciousness.

Second, Ibn 'Arabī constantly remind his students to grow in direct proportion to their own level of increasing spiritual awareness and intelligence, since true communication and right action in this world depend on an accurately informed and empathic awareness of the actual potential for realization within each particular individual with whom we are communicating and interacting.

Third, the movement from verbal familiarity, through intellectual conceptualization, to a realized, experientially

ideas between mysticism and philosophy comes out of the tradition of commentary upon the Fususs al-Hikam. Cited from Caner K. Dagli, "From Mysticism to Philosophy (And Back): An Ontological History of the School of Oneness of Being" (Ph.D. Dissertation, Princeton University, 1996), ix.

${ }^{16}$ Morris, The Reflective Heart, 356-9.

17The term "Tradition" refers to perennial wisdom and teachings found in all traditions. While conventional education is primarily aimed at training individual to earn a living, Traditional education is aimed at training the individual in self realization. Compare to M. Ali Lakhani, "Education in the Light of Tradition: A Metaphysical Perspective," in Education in the Light of Tradition: A Metaphysical Perspective, ed. Jane Casewit (Bloomington: World Wisdom, 2011), 27. 
grounded awareness of the actual realities underlying key Qur'anic symbols and the wider field of divine "Signs."

Some scholars have pointed out that Fusiss, in essence, is only an intensive study in the interpretation and proper understanding of the Qur'an, since its worldview and its relation to Qur'an are presented for consideration as a thoroughly applied method of interpretation, focused on revealing the allusions and consistent symbolic language presented in the most verses of Qur'an. Of course this Qur'anic focus is supplemented by the related background of relevant hadith and the traditional "stories of the prophets" regarding the key figures in many of its chapters. This emphasis highlights Ibn 'Arabï's conviction that ultimate truth can only be perceived with the help of divine guidance, and his clear awareness that this divine guidance and meaning has taken certain specific forms, concerning which the Qur'an itself has said: 'Enter the houses by their doors" (Q 2:189).

Morris notes that from this symbolical language, we can derive Ibn 'Arabi key understanding of spiritual intelligence as spiritual realization (tahqiq). He said,

It is also important to note that the particularity of Ibn 'Arabîs familiar rhetorical approach in his works involves not only using symbolical language, but also a careful strategy of ongoing "de-construction" that provokes his readers' and students' initially unexamined religious beliefs and language, designed to restore them to a more direct awareness of the actual, immediate references to those familiar religious symbols and allusions. ${ }^{18}$

This challenge of language is rooted in the inherent tensions involving the actual realities and process of what can call "spiritual intelligence," or 'aql in its usual Qur'anic sense. Ibn 'Arabi’s rhetorical strategy-everywhere, but perhaps most pointedly and notoriously in his Fususs al-Hikam-is to try to oblige his students to begin to develop and pursue the practice of "spiritual discernment" and understanding that can convey simultaneously the multiple, integrally related meanings of the divine "Signs," both in scripture and in all the particulars of our

${ }^{18}$ Morris, The Reflective Heart, 186. , p.186. 
lives and selves, through our inner faculties of true spiritual perception and penetration.

According to Ibn 'Arabī, because revelation is addressed to all people, it must convey meaningful messages to the spiritual elite as well as to the generality of the people-and the plural here means that those "messages" are likely to be different, and understood differently, by people of different aptitudes and experience, in different situations and circumstances.

\section{Revealing the Wisdom of the Prophets}

Many commentators of Ibn 'Arabi's works who know well his central teaching will define it as wisdom, both as generally applied by many Sufis, and particularly as it is understood from the writings of Ibn 'Arabi himself. Chittick, for example, indicates that wisdom is "knowledge of the realities of things as they are in themselves ('ala má hiya 'alayb) and activity ('amal) in keeping with that knowledge."

Or again, it is "knowledge of the realities, attributes and properties of things as they are in themselves along with volitional words and deeds that are necessarily correct." 19

Traditional definitions of hikma, he goes on to explain, almost invariably combine ilm and 'amal, knowledge and works, theory and practice. Moreover, the knowledge that wisdom encompasses is true, since it corresponds to things as they are in themselves. In Sufism this means that the knowledge is not only of concrete things in this world, but also of the "realities," i.e., of the immutable entities, of things as known directly by God. In addition, wisdom is connected to proper and appropriate activity. When a "wise man" performs an act, it will always conform to the ultimate necessities of the situation. ${ }^{20}$

As the explicit title and subject of the book itself is divine "wisdoms" (bikam), Fususs al-Hikam is deeply concerned with discovering how the prophets who are taken up in each chapter exemplify different facets of the deeper spiritual process of the divine-human relation that is so often mentioned in the Qur'an:

19‘Abd al-Razzāq Kāshānī, Sharh Fusūus al-Hikkam (Qum: Intishārāt Bīdār, 1380), 7.

${ }^{20}$ Chittick, "The Chapter," 6. 
"Surely there is a Reminder in that for whoever has a heart, or listens attentively, while he/He is witnessing" (50:37). ${ }^{21}$

Through the opening section of Fusüs al-Hikam, the underlying conception of divine revelation here indicates that each facet of divine Wisdom-here analogous to the divine "Ringstone" or jewels of wisdom-is made known according to the distinctive receptivity of each human recipient, who becomes the human manifestation (a sort of "bezel" or peculiarly shaped receptacle) for the divine wisdom exemplified and communicated through this or that prophet. As the opening chapter on Adam makes clear, the particular receiving "knower" himself is also of divine origin, inasmuch as he is identified essentially and in an unfathomable way with the divine archetype of each prophet.

In the Fusüs al-Hikeam, in particular, Ibn 'Arabi highlights the ways that each of the prophets are a direct Sign representing the messages of God for a specific purpose, focusing in each chapter on their unique ways of effectively calling their respective peoples toward God. This discussion of the spiritual rhetoric and communications of these very different prophets as the "Words" of God helps him to explain more generally how the Divine Names manifest themselves directly in the world, and Ibn "Arabī applies this principle of "divine communication" to investigate the very workings of the universe and the activity of nature, ${ }^{22}$ including the nature of human beings. Thus, as the Qur'an says, every prophet and apostle brings not only a scripture, but also deriving from his sanctity, a particular divine wisdom that is a wisdom of realization (Q 2:51).

Hence the prophets taken up in Fusüs al-Hikam (in a few representative chapters), illustrate the wider processes of divine and human dialogue, "calling" and response, mentioned in the Qur'an. Now since those prophets' teachings, and the specific details of the presence and utterance or expression of them, are understood to be divinely inspired, they therefore illustrate the

${ }^{21} \mathrm{On}$ listening as contemplation by the purified Heart, see Morris, The Reflective Heart, 46. The same verse figures prominently in the fass of Shu'ayb, in Ibn 'Arabî's discussion of the true spiritual Knowers ('urafa').

${ }^{22}$ Chittick, "The Chapter," 5-6. 
kind of specifically spiritual knowing (ma'rifah) discovered through self-awareness. As such, all the details of their actions and teachings are seen by Ibn 'Arabī as illuminating this book's central question of our universal human awareness of the divine Names/Attributes, which are always distinctive qualities we become aware of in creation ("on the horizons and within the souls").

Practically speaking, Ibn 'Arabî's discussion of these features of each prophet's teaching is framed so as to help his readers to see how these accounts highlight each individual's (and each different "people's") different capacities for perceiving the divine Qualities and Names through the aspect of the "inner Self-manifestation" (tajalli)-i.e., the particular unique "bezel" of spiritual preparedness and aptitude (isti dadd) —of each particular human soul. Thus we come to discover how to best awaken or increase the awareness of those particular Names through what we learn - in our own lives, as in these symbolic tales of the prophets-from their associated stories or "dramatizations" 23 of each prophet and the responses of his people. And through that illuminated awareness, we can come to recognize what is demanded of us, in action and response, through our heightened awareness of those particular relevant divine qualities or Names. All of this is encapsulated in the famous "hadith of the supererogatory works" (nawafil) that is alluded to repeatedly throughout the Fusüs al-Hikam: that deeper spiritual knowing flows from our appreciation of the contributions of our religious "duties" (farä'id) and especially the further actions and practices flowing from them (the nawafii), which eventually lead each of us toward the inspired types of awareness and active perfection that are so memorably exemplified by these archetypal "Folk of God" (qawm: at Q. 5:54). All of these issues will be examined here to illustrate the different ways that Ibn 'Arabì uses them to turn his readers toward his guiding aim of an ever-deepening understanding God.

23We prefer the term "dramatization" to describe how these prophets teach (and God teaches), because they are indeed given "telling examples" (mathal/ amthä), and the inner meaning and intention of those examples is only apparent in the particular situations in which they arise. 
His treatment of these prophetic stories in the Fussus alHikam continuously raises new dimensions of our spiritual journey through realization (tahqiq), by bringing up related ideas, theories, and practical challenges for our examination as to what he means here as "wisdom," through the basic question of what each of the prophets in the Fusus are trying to show: i.e., the question of what their example can teach us about discovering and applying their wisdom in all the related lessons of our own life. Though one can find memorable illustrations of this idea among virtually all the chapters of the Fussus, in this essay we will only look at the two selected chapters (on Hud and Muhammad) where Ibn 'Arabi more fully articulates his understanding of knowing God.

\section{Learning in Each Soul's Spiritual Path (Tariq) as the Manifestation of Divine Proximity: the Wisdom of Hūd}

In this section, based on the chapter on the Wisdom of Hūd, what can be overviewed is on the divine Proximity. This very central idea about relation of God and His beloved creation can be seen in terms of :1) the Divine Calling and Response; 2) the Straight Path (sirät); and 3) the Heart and divine proximity through all our experiences of testing and purification ("punishment"). In the fass of the prophet Hūd, Ibn 'Arabī openly stresses this ever-present divine closeness to the servant:

"We are nearer to (the human being) than his jugular vein." ${ }^{24}$ No person is distinguished from another (in this respect). There is no concealment in the Divine Sayings regarding the divine closeness to the servant. There is no nearness greater than His Selfhood being the very bodily parts and faculties of the servant. For the servant is none other than these bodily parts and faculties. ${ }^{25}$

This closeness is also a full awareness of God's Presence(s) which is the culmination of the human condition of being "vicegerency" (or stewardship: kbilafa) and servanthood, experienced and expressed in all states and actions (particularly for fully human being (insān kämil), whether in the obligatory

${ }^{24}$ Qs. 50:16.

${ }^{25}$ Muhyi al-Dīn Ibn 'Arabī, Fusūṣs al-Hikam, ed. A. 'Affifi (Beirut: Dār alKutub al-'Arabī, 1946), 108. 
acts of worship or in all the rest of life (i.e., the "supererogatory" works or nawaffid). All of these dimensions of servanthood and divine knowing, both practical and metaphysical, are summed up in the following famous Divine Saying (badith qudsi) often called the "hadith of the Wali (the "Friend" of God)":

... And My servant does not come near to Me with anything more lovable to Me than what I have made a duty for him. And My servant continues to come nearer to Me through the further acts of devotion (nawajfi) until I love him. Then when I love him, I am his hearing with which he hears, his sight with which he sees, his hand with which he holds, and his foot with which he walks. And if he asks Me, I most surely give to him. And if he seeks My help, I surely help him...."26

Ibn 'Arabì begins here by emphasizing that the proximity of the Divine is not exclusive to anybody, as the Qur'an makes clear. However, in the context being discussed here, the Shaykh focuses on the particular dimension of that closeness stressed by the hadith of supererogatory works (qurb al-nawaffil): namely, that God (al-Haqq) is present in all of our perceptions and in all of our actions-both symbolized here by the references to the servant's hearing and seeing, hands and feet. Through this expression of the comprehensive Divine nearness of al-Haqq, Ibn 'Arabi is explaining that the identity and very existence of the servant is none other than the being (mujuid) of al-Haqq. At the time, the fully realized human being will integrate and appropriately manifest all the Names and Attributes of al-Haqq as hearing, sight, will and so on. This is the result of his realized awareness of this divine Proximity (qurb al-farä'id).

Moreover, Ibn 'Arabī goes on to establish a close relation between this divine Proximity, the inward processes of spiritual “journeying"(sulūk) and each individual soul's particular spiritual path (tariq), especially throughout the fass of Hud. He opens there with the Qur'anic verse (11:56):

${ }^{26}$ See W.A. Graham, Divine Word and Prophetic Word in Early Islam (The Hague, 1977), 173., Saying 49, The reference to God's special protective Love for His "Friends" is at the beginning of this long "Divine Saying." 
"There is no creature that crawls, but He takes it by the forelock. Verily my Lord is on a straight path." Anything that walks is on the straight path of its Lord. ${ }^{27}$

We can mention that the creative manifestation of divine "Lordship" (rubübiyyah) is the active aspect of each divine Name. This is what reveals the "direct path" connecting each Lord/Sustainer (Rabb) and Its servant (marbüb), so that through this path the servant can have a relationship to-and eventually manifest in intentional action-the divine Names. The manifestation of this relationship is the "Straight Path" (al-sirät al-mustaqim,1:6). Because all the Names have affinity to God (Alläh) as the "all-comprehensive" Reality which is the essential Reality encompassing all Divine Names, thus each Name is able in some way to lead back or elevate the servant toward a deeper realization and manifestation of God. And through these endless manifestations, the creatures are able to reach Allah (the Divinity) in all their diversity. In other words, Allah sustains and maintains the Straight Path (al-sirät al-mustaqim), through all the creatures that are inherently on this path. For as Ibn 'Arabi stresses here, there is not anything excluded from this path.

Though all humans are on the straight path, there are those who are inwardly aware of following a path and of its Destination, and others who are momentarily unaware of being on a path and of their destination. Consequently, there are two different ways of spiritual "journeying" (sulük), though both groups are still "on the Straight Path" with their Lord. The seeker would be led by a particular Rabb to be "on a path" until they reach that ultimate Reality which is all-comprehensive. In other words, there always a Path from God to us, while from us to Him is only through His Way, by and with Him.

Yet from our practical human perspective of properly perceiving and responding to God's Calling and Guidance, it is essential to perceive this relationship much more closely and accurately, in its full particularity and individuality. For Ibn 'Arabī, this ongoing practical challenge is beautifully illustrated

27Ibn 'Arabī, Fușūs al-Hikam, 106. Dagli, Ibn 'Arabi, 105. 
and dramatized through the contrasting dramatic stories of the ways Noah and Hud interact with their respective peoples.

In the fass of Hud, Ibn 'Arabī stresses the special kind of spiritual knowledge which comes from our peculiar human relation with "the lowest of the low" 28 which he calls "knowledge through the feet" ("ilm al-rij)-i.e., the knowing that can only come through actually traveling through all the tests and lessons of the earthly human existence. "Whosoever knows that the Real is identical with the Path, knows the affair as it is." ${ }^{29}$ This is the knowledge that we develop through sulük, through actual "journeying" upon our particular "way" in life. Because the actual experience of journeying (at least in Ibn 'Arabì's time) was primarily through the feet, and so the reality of suluk must be learned through actually walking upon the path. Through this we can recognize the kind of knowledge discovered through practice. Ultimately, the spiritual journey is a journey of consciousness, an inner journey in which the traveler (sälik) gradually becomes conscious of the Presence of the divine Reality (Haqiqat) from one degree to the next degree, as that Reality is manifested-and then experienced-in all the stations of the divine Acts ( $\left.a f^{\prime} \bar{a} \bar{l}\right)$, Attributes (sifät) and Essence $(d h \bar{a} t)$. Sulük is therefore ultimately a journey of "interiorization" and "particularization" - but at the same time, a journey that is always taking place within the framework of all the concrete manifestations of those divine Names in our world and in all the creatures we encounter in it.

When "the veil is lifted," Ibn "Arabī acknowledges, then the spiritual traveler will recognize the inner reality of this journey, traveler, and those particular life-circumstances and situations that are being "walked upon." This experiential knowledge can only be acquired through our life and active participation in

28 Asfal al-säfilin: This phrase is taken from the Qur'an 95:4-8. That Sura provides the basic framework for this entire chapter (Hūd), since it emphasizes the essential role of the tests and trials of earthly life in bringing about the spiritual maturity and wisdom of the initially pure, but naïve and ignorant human spirit, and concludes by highlighting God's supreme Wisdom in making this education possible.

29Ibn 'Arabī, Fuṣūs al-Hikam, 109. 
"this lower life" (al-dunya), which is what the Qur'an refers to (in Sura 95) as the "lowest of the low," asfal al-säfilin. As this Qur'anic passage makes clear, human beings are "brought down" to this plane of existence because perfection cannot be achieved if the people do not go through and learn to recognize the full reality of the divine Presence (meaning, intentions, etc.) in all the degrees of its manifestation.

Of course the lessons that are most memorably learned in the process of that worldly inward journey often involve testing, suffering, and all the forms of what the Qur'an terms "recompense" or consequences of our actions, which can be subjectively perceived as a kind of "punishment." Ibn 'Arabī seems to make this point explicitly in regard to the fate of those people of 'Ad, who ultimately resisted and denied the call brought by their prophet Hud:

He made the "wind" (rīh) an indication of the comfort (räha) therein. By this wind [that destroyed them and the "city" of their earthly existence] He relieved them from those darkened temples, rugged paths, and veils of pitch. There was torment ('adbäb) in that wind, and that is a thing which they would find to be sweet ${ }^{30}$ after having tasted it, though it would hurt them by separating them from what was familiar. He carried out the torment, and this thing was closer to them than what they had imagined. ${ }^{31}$

The people of 'Ad thought that the dark clouds approaching them were bringing beneficent rains, not destructive storms. But Ibn 'Arabī points out that even this wind is a Sign that contained an eventual comfort or release (räha), which is an indication of their state after death. Because through this initial destruction they would be relieved and freed from their particular life (i.e., their earthly ego) that had been pulling them into the darkness, and which was full of distress and veils.

30"Torment" (or "punishment") and "sweetness" here both come from close forms of the same Arabic verbal root " $-d h$-b. See ibid., 94.: "It is called torment because of the sweetness of its food." Here he is intentionally using the paradoxical double meanings of the Arabic root, which can be understood as either "torment" or "sweetness"- since what would be "torment" for a pure human spirit is often initially perceived as "sweet" by a corrupted and imperfect soul (and vice-versa).

31Ibid., 109. 
Although outwardly the wind contained a torment and brief pain that separated the people of 'Ad from the enjoyments they had felt during their lives, Ibn 'Arabì points out how that brief pain contained a hidden grace, just as what we experience subjectively as Divine wrath always contains a deeper and more lasting Love and Mercy - and just as the wise likewise perceive that within each Name of divine Beauty (Jamäl) there lies an aspect of divine Majesty (Jalä). So the people of 'Ad will feel the sweetness that comes from the destruction of their attachments, although they will also perceive that initially as a kind of "torment" or even some deserved punishment. And from that larger divine perspective which Ibn 'Arabī is revealing to his readers here, all of this process is "closer to them than what they imagined." 32

For God, all apparent "distance" in this process is already nearness, though it takes much time and patience for human beings to recognize this and then to begin to act accordingly. Because when people imagine that the reality is not one, this illusion itself brings them to a place and state of "torment" that they may well view as "punishment." But through this inner torment, their illusion is lifted and the illusory veils of their persona, their "ego-self are gradually "burned away." Then they realize that God's distance was itself an illusion that they had nurtured. When Gehenna (i.e., this apparent earthly distance from God) has been transformed into the unveiled awareness of actual nearness, they can truly begin to know and recognize God in all of His inner and outer Signs. But this "unveiled" vision can only happen after the divine Name "The Avenger" (alMuntaqim) has purified them.

When one encounters such passages in the Fususs, what is immediately highlighted are all of the reader's normally implicit and unexamined dualistic judgments and assumptions (Beauty and Majesty, heaven and hell) that in fact continue to govern our initial unconscious patterns of striving and action in the world. As Ibn 'Arabì goes on to explain here:

In these acts they were taking steps on the straight path of their Lord, for "their forelocks were in the Hand" (Qur'an 11:52 and 96:15-16) of

32Dagli, Ibn 'Arabi, 110. 
Him to Whom his description belongs. They did not walk by themselves, but walked under compulsion to arrive at none other than closeness. $^{33}$

This last description goes to the very heart of what Ibn 'Arabi' is suggesting here in pointing to the Presence of the Real within and throughout that Path which englobes us and all of creation. And this process of knowing the self must therefore continue to unfold throughout that journey, at every stage of our path.

\section{Learning through Divine Love: the Wisdom of Muhammad}

In the case of Ibn 'Arabī, though he was not always enthusiastic about the famous "ecstatic sayings" popularly associated with certain earlier Sufis, his own approach-which is always grounded in teachings drawn from the Qur'an and badith_often focuses on God's love as both cause and the consequence of His inner longing for Self-disclosure, as expressed in the celebrated divine Saying of the "hidden Treasure": "I was a hidden Treasure, and I loved to be known; so I created people/creation so that I might be known." Nowhere is the centrality of divine Love in his teaching more evident than in the Fususs, where he devotes the entire concluding chapter on Muhammad to a discourse on divine and human Love.

Ibn 'Arabì beautifully summarizes and presents the complex modalities of the interrelations between love, creation, identity, and knowing the self and knowing God-which have run like a hidden unifying current throughout all the earlier chapters of the Fusüs-in the famous concluding fass of Muhammad, where he bases his approach to love on one of the famous Prophetic sayings: "Three things bave been made beloved to me in this world of yours :women, perfume, and prayer (salät), the solace of my eyes." 34

Since the Prophet curiously mentioned "women" first, and prayer only at the end of this list, Ibn 'Arabì begins by

33Ibn 'Arabī, Fușūs al-Hikam, 108. Dagli, Ibn 'Arabi, 108.

34Ibn 'Arabī, Fusūus al-Hikam, 214. 
commenting that this is perhaps because the woman is a "part" of man (Adam). After that, he mentions that our inner knowledge of our self as the true human being (ma'rifat al-insān) comes before our knowledge of our Lord. This latter statement, if we interpret it in the context of love, suggests that love of our (true) self is the necessary foundation for the love of all others:

For man's knowledge of himself precedes his knowledge of his Lord. Indeed his knowledge of his Lord results from his knowledge of himself. That is why he said: "He who knows himself knows his Lord." If you wish, you can say that the knowledge spoken in this saying is impossible, or that one cannot attain to it, although it allows for this. Or if you wish, you can acknowledge this knowledge. The first [decision] means that you cannot know yourself, and hence cannot know your Lord. The second means that you can know yourself, and hence can know your Lord. ${ }^{35}$

Here Ibn 'Arabì explains this statement as indicating that self-knowledge must precede our (truly) knowing the Lord. ${ }^{36} \mathrm{Or}$ it could also be interpreted as saying that as a person comes to know himself and his perfection (as the rüh of the insān kamil), then he will also come to know God in the vast context of the ever-renewed creative manifestation of His Names and Attributes. So Ibn 'Arabī has allowed for two possible meanings of this famous hadith/saying: either negative and "apophatic," or positive and "cataphatic."

Knowing the self (ma'rifat al-nafs), therefore, is knowing the very reality of self, which is God (al-Haqq). Ibn 'Arabì makes this statement in the context of a referential "indication" (dalī) or scriptural proof. However, the statement is actually a continuation of the insight that such a reference is really God's proof for Himself. Thus, knowing one's self is the actual proof of knowing the Lord. When he states that the proof is a proof for itself, since human self-identity turns out to be inseparable from its divine Source, then the human being's self-identity is the existential evidence for al-Haqq Himself.

35Ibid., 215.

36 See more details about this particular discussion in our article, Herawati, "Concerning Ibn 'Arabi's Account of Knowledge of God (Ma'rifa) al-Haqq," 219-42. 
Referring to Ibn 'Arabi's brilliant idea on the wisdom of Muhammad, that is the the Divine Love, we may derive some particular aspects from it. First, love signifies the strong attraction that draws all creatures back to reunion with the Creator. Love generates love, and God alludes to this in the famous lines of the Qur'an (referring to that saving "Folk" (qawm) who are the divine "Friends," awliyal' Alläb): "...whom He loves, so they love Him (yubibbubum wa yuhibbuinabu)" (3:29). In a motif that runs through all the masterpieces of Islamic mystical poetry, since the spirits were apparently separated from their divine Source upon their descent into bodies in this world, they have become "old friends," so that once we meet our old Friend, that will also be the soul's "re-union."

Second, Love is essentially a dynamic force. It makes human beings strive toward the object of desire that, under the effect of the attraction of love, is in return irresistibly drawn toward the one who desires it. Last, Love indicates how human beings differ from all other creations. According to the famous divine Saying mentioned often above, it was because God "loved to be known" that He created the universe and people "in order to be known," to provide an opportunity for that primordial love to be known and experienced in all its dimensions. To experience love is essential to understanding our humanity and our ultimate purpose, and therefore the very reality of God. The reality of God is love. To love is thus to experience and manifest God.

This mutual divine Love-and the longing, questioning and dynamic seeking it inspires - thereby becomes essential to the ways people can come to that deep inner knowledge of one's soul/self which is attained by the prophets and the Friends. As we have just seen in the chapter on Hud, knowledge of one's soul, however, does not lie in any tendency to cut ourselves off from the world, as though this life were simply a kind of distraction. Within Ibn 'Arabī's metaphysical understanding of creation as divine Self-manifestation, the divine Beloved can (and ultimately must) be perceived and witnessed throughout His Self-manifestations in creation, and Divine Love itself is perceiving and being lived out through all the different forms of earthly love. That is why Muhammad was aware that his love for 
women (as for "perfume and prayer") all derived from the divine Love, because God grants each thing its created character (khalq), which is that which is rightfully due itself. ${ }^{37}$

In other words, from this perspective, the manifestation of human love for God is itself an effect of God's pre-existing and abiding Love for the human being, and indeed for all His creation. So if true love increases in proportion to knowledge, he who knows God best loves Him most. The aim of this divine Love is not to produce some set of pious actions as much as possible, but rather above all to prepare ourselves for Him to perform or manifest Himself-and then to respond to that discovered Love as He wills. The aim of this Love requires always seeking the Real Beloved (in all the divine Names) manifesting behind and through the "masks" of created existence. And the deepest expression of that realization of Love is of course prayer-hence the inner coherence (and practical progression, from the earthly to the purely spiritual) between the three successive "objects of Love" mentioned expressly in this badith.

Yet as this same divine Saying also reminds us, this divine Love does not simply bring about creation and existence. Its multifarious influences of attraction and passion, its awakening of irresistible mystery, and the providential "plotting" (makar) of its eventual consequences in each soul's destiny-as we can see in every dimension of human existence, in this world and beyond-also lead us inevitably from not-knowing to the deepest forms of awareness, knowing, and active compassion (rạ̣ma).

For as Ibn 'Arabì points out-explicitly here in the conclusion to the Fususs, and implicitly in its opening chapter on Adam-this primordial relationship and inner correspondence (munāsaba) of Creator and creature, "lord" and "servant," is established in the fact of humankind's being created "in the image of God, the All-Loving and All-Compassionate." 38 Therefore true, divine Love must be seeing and knowing, always moving between spiritual contemplation and active expression.

37Ibn 'Arabī, Fusūs al-Hikeam, 219. Dagli, Ibn 'Arabi, 248.

$38^{\prime}$ Ala surat al-Rabman, in the words of a famous hadith regarding Adam. 
Ibn Arabī draws two main conclusions from that hadith with regard to defining the roles of Love more specifically: (a) on the one hand, that on a macrocosmic level, all creation, all divine Self-manifestation originates in divine Love; and (b) on the other hand, from the initiatic, practical spiritual point of view of our human microcosm, that love and knowledge-which are the key terms in this hadith ("I loved to be known") - are conceptually distinct, but existentially inseparable and parallel. From our subjective perspective, it might at first seem that love precedes knowledge, but deeper reflection will quickly reveal the knowing that was already there, "before" and embedded within our first budding recognition of that Love. ${ }^{39}$

For Ibn 'Arabi , all of this simply expresses what the Qur'an explains to us about this central human task: namely, that (a) God's infinite "Signs" are what we witness and experience "on the horizons (ufuq) and in our souls (anfus)"; (b) that we must first begin simply by actually "seeing" or "scrutinizing" and "paying attention" to them, precisely as Signs; and (c) that attention must then be combined with our deepest efforts of reflection, penetration and discernment. When this process is carried out (d) with patient dedication over the requisite periods of time and testing that are dimensions of our nature's essential "closeness" with God (qurb), including purifying suffering and perseverance (sabr) —and (e) intense mutual Love, the dynamic motivating force for all human transformation: when all of those elements have been suitably brought together in the Heart, then together with the indispensable element of grace (tanfiq), all this may result in true spiritual knowing ('ilm) and awakened recognition (ma'rifa) of God's Presence. ${ }^{40}$

${ }^{39}$ Hence there is almost no classical Sufi poem, in any language, that does not invoke, directly or implicitly, the cosmic "Love-story" of the primordial Covenant that is embedded in the Qur'anic account of God's questioning of all the human souls in their purely spiritual, pre-temporal state: “Am I not your Lord?' (Qur'an 7:172-173).

40See James Morris, "Communication and Spiritual Pedagogy: Exploring the Methods of Investigation (tahqiq) in Classical Islamic Thought," in To appear in Time, Space and Motion in Islam, ed. H. Ahmed (Washington: Islamic Thought and Science Institute, n.d.). 
Now when we try to represent this approach more dynamically and realistically, one of the images to emerge from this seems to be that of a kind of metaphysical cross, in which the vertical plane indicates the human connection with the divine and the descent of "grace" and unfolding "blessings" of illumination and inspiration into the Heart. On the other hand, the horizontal plane represents the playing out of this most profound experience in space and time, in the course of our worldly life and beyond ("returning" to God).

\section{Conclusion}

What can be learned from Ibn 'Arabi through his understanding of this divine prophetic wisdom outlined throughout his Fuṣuṣ al-Hikam, is, that every human being response Divine Call through their particular Lord. However, those who are aware and walk and those who are not aware. For those who are aware, they know that they actually traveling the path through all the tests and lessons of the earthly human existence. Because the actual experience of journeying was primarily through the feet, then the reality of sulūk must be learned through actually walking upon the path. This is the wisdom of Hud. Furthermore, through the wisdom of Muhammad, Ibn 'Arabi teaches us that the aim of the divine Love is not to produce some set of pious actions as much as possible, but rather above all to prepare ourselves for Him to perform or manifest Himself - and then to respond to that discovered Love as $\mathrm{He}$ wills. The aim of this Love requires always seeking the Real Beloved (in all the divine Names) manifesting behind and through the "masks" of created existence. This is a kind of dynamics of life, the education and the art of life. Thus in our own lives, the impact of this realization reveals itself only gradually, expressing itself in our daily activities as practice and action, transformed faith and vision, and in the decisions we make, whatever forms they may take. The interplay of both axes (vertical and horizontal) frames and forms the unique story-and indeed it is always a dramaand that divine Blessing which each individual is asked to "recount". 


\section{References}

al-Kisā'i, Muhammad ibn 'Abd Allāh. Tales of the Prophets (Qiṣaș al-Abiy $\left.\bar{a}^{\prime}\right)$ Translated by Wheeler Thackston. Chicago: Great Books of Islamic World, 1997.

Chittick, William C. "The Chapter Headings of the Fuṣuṣ." the Journal of the Mubyiddin Ibn' Arabi Society 2 (1984).

------. The Sufi Path of Knowledge: Ibn al-'Arabi's Metaphysics of Imagination. Albany, NY: State University of New York Press, 1989.

------. Ibn 'Arabi, Heirs to the Prophets. England: One World, 2005. Dagli, Caner K. "From Mysticism to Philosophy (And Back): An Ontological History of the School of Oneness of Being." Ph.D. Dissertation, Princeton University, 1996.

------. Ibn 'Arabi: The Ringstones of Wisdom. Translated by Caner K. Dagli. Chicago: Great Books of the Islamic World, 2004.

Emmons, R. A. The Psychology of Ultimate Concern: Motivation and Spirituality in Personality. New York: Guilford Press, 1999.

------. "Is Spirituality an Intelligence? Motivation, Cognition and the Psychology of Ultimate Concern." The International Journal for the Psychology of Religion 10, no. 1 (2000): 3-26.

------. "Spirituality and Intelligence: Problems and Prospects." The International Journal for the Psychology of Religion 10, no. 1 (2000): 57-64.

Graham, W.A. Divine Word and Prophetic Word in Early Islam. The Hague, 1977.

Herawati, Andi. "Concerning Ibn 'Arabi's Account of Knowledge of God (Ma'rifa) al-Haqq." Kanz Philosophia : A Journal for Islamic Philosophy and Mysticism 3, no. 2 (2013): 219-42. http://dx.doi.org/http://dx.doi.org/10.20871/ kpjipm.v3i2.49.

Howard, Barbara B., Precious Guramatunhu-Mudiwa, and Stephen R. White. "Spiritual Intelligence and Transformational Leadership: A New Theoretical Framework." Journal of Curriculum and Instruction (JoCI) 3, no. 2 (2009): 54-67 (November). 
Ibn 'Arabī, Muhyi al-Dīn. Fusūṣ al-Hikam. Edited by A. 'Affifi. Beirut: Dār al-Kutub al-'Arabī, 1946.

Ibn Kathir, Imām 'Imād al-Dīn Abū al-Fidā' Ismā'îl ibn 'Umar. Stories of the Prophets. Riyad: Maktabah Dār al-Salām, 2003.

Kāshānī, 'Abd al-Razzāq. Sharḥ Fuṣụs al-Hikeam. Qum: Intishārāt Bīdār, 1380.

Lakhani, M. Ali. "Education in the Light of Tradition: A Metaphysical Perspective." In Education in the Light of Tradition: A Metaphysical Perspective, edited by Jane Casewit. Bloomington: World Wisdom, 2011.

Lings, Martin. Muhammad: His Life Based on the Earliest Sources. Lahore: Suhail Academy, 1983.

Morris, James. "Arabī and his Interpreters." the Journal of the American Oriental Society 106 (1986): 539-51.

------. The Reflective Heart: Discovering Spiritual Intelligence in Ibn 'Arabi's 'Meccan Illuminations'. Louisville KY: Fons Vitae, 2005.

-------. "Communication and Spiritual Pedagogy: Exploring the Methods of Investigation (tahqiq) in Classical Islamic Thought." In To appear in Time, Space and Motion in Islam, edited by H. Ahmed. Washington: Islamic Thought and Science Institute, n.d. 